\title{
HIHIKO O MANGARAUTAWHIRI: POWER SOVEREIGNTY FOR A PROSPEROUS WHĀNAU AND HAPŪ
}

\author{
Hermione McCallum-Haire \\ with Rihi Te Nana and Joanne Gallagher
}

\section{KO NGĀTI HINEMIHI E NGUNGURU NEI!}

By way of centring this research, it is tika that the whakapapa of our hapū Ngāti Hinemihi be the korero that begins this article. No reira e rau rangatira mā...

\author{
Ko Tongariro te maunga \\ Ko Taupō te moana \\ Ko Te Arawa te waka \\ Ko Tūwharetoa te iwi \\ Ko Ngāti Hinemihi te hapū \\ Ko Te Heu Heu te tangata
}

The ancestor from whom Ngāti Hinemihi descends is the tohunga Ngātoroirangi, the high priest ofTe Arawa canoe. The ancestors to whom the tribe traces descent for rights to land in Taupō district are Tia and Kurapoto, who both came in Te Arawa, and the sons and certain grandsons of Tūwharetoa.'

John Te Herekiekie Grace writes that Tūwharetoa had every gift that a beneficent providence could bestow. He was notably born and a powerful chief who ruled vast domains, possessing a great deal of personal charm and physical stature."' His intellect matched his other qualities, and it is said that his tutors could scarcely keep pace with him. He had the natural gift of expression of his ancestors and became acknowledged as the finest orator of his time. Unlike many chiefs of his day, he avoided conflict with other tribes unless provoked: and he never committed his tribe to expeditions that took them into other lands unless it was to their benefit."3

A mokopuna of Tūwharetoa, Tutetawha was later involved in an incident of claiming land that is of direct interest to the Ngāpuke area, which was then handed down from generation to generation. Tutetawha and his brother decided to travel to the country situated to the west of Lake Taupō, with the intention of 'laying claim to Tuhua' near Taumarunui. When they reached what is now called the Puketapu Block, and through which the present TaumarunuiTürangi highway passes, they heard the trumpet of Te Kanawa, a powerful Maniapoto chief who was also in the vicinity claiming land for his people.

Eventually, Tutetawha returned to Lake Rotoiaira, where he was later to marry Hinemihi, an ancestress from the Mātaatua people. She lived atWhakatāne and wanted to meet Tutetawha. After her party reachedTokaanu, they then crossed the range of hills separating Lake Rotoaira from Lake Taupō. When they finally arrived at the pa of Tutetawha, and when it was known that the visitor was Hinemihi, a great feast of welcome was prepared.

Hinemihi and Tutetawha had four children, Te Rangiita, Tuarakino, Paraparaahika and Turumakina. The many descendants of this couple represent the two hapū of Ngāti Tūwharetoa, these being Ngāti Hinemihi and Ngāti Turumakina. 


\section{PURPOSE}

The aim of the Hihiko o Mangarautawhiri research project is to explore sustainable energy options for the Te Mangarautawhiri a Pukehou Trust. This research is a response to the excessive electric power and lines costs that whānau and hapu have paid since 2007. These outrageous power costs are compromising the health and wellbeing of whānau. The Te Mangarautawhiri a Pukehou Trust, who are members of Ngāti Hinemihi (NH), have chosen to partner with Ngā wai ā Te Tūī, Māori \& Indigenous Research Centre, Unitec Institute of Technology (NWATT) to develop this research project on behalf of their hapū. In the context of this proposal, the whakataukī (proverb) above reflects the deep-rooted traditional cultural practises that founds philosophical and mode of operations. A united hapū represents agreement and a sense of purpose that will deliver positive outcomes for Te Mangarautawhiri à Pukehou Trust (TMaPT) and $\mathrm{NH}$.

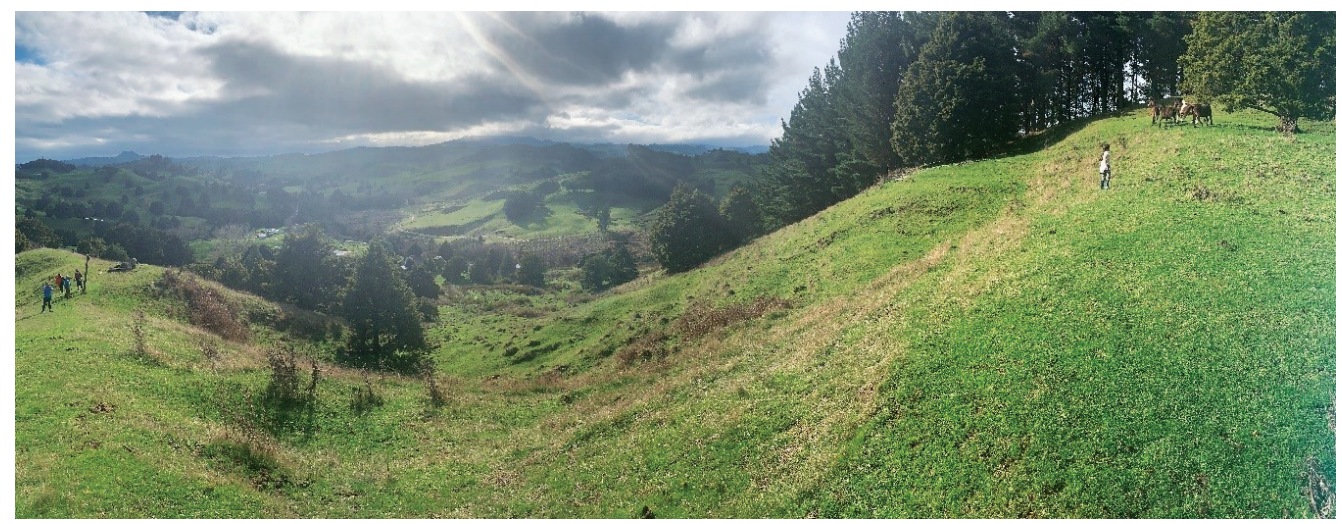

Figure I. Photograph taken from a ridge behind the Keepa farm.

This photo (Figure I.) is taken from a ridge behind the Keepa farm, which is located 10 kilometres outside of Taumarunui, in the heart of the King Country, or Te Rohe Pötae. The valley's original name is Mangarautawhiri, which in English roughly translates to the valley of a hundred winds.

The name of the Keepa whānau trust is Te Mangarautawhiri à Pukehou.

\section{THE POWER COMPANY 'RIP-OFF'}

As a result of the New Zealand electricity reforms of the 1980s and 90s, people who live in Te Rohe Pōtae (King Country) and the western lands of Tüwharetoa have no option but to pay two separate power bills: one to an electricity provider, and another to a line company, for the use of their powerlines. Ngāti Hinemihi ki Tüwharetoa is one of many hapū that must live under these electricity-regulated conditions. Residents have reported a 77 percent increase in their line charges, and the cost of the 'line rental' is often four times the cost of the actual power they consume. For many low-income whānau, kuia and kaumātua, this has often resulted in going without electricity. ${ }^{4}$ The use of the term 'Power Sovereignty' as a double entendre is about asserting rangatiratanga whilst addressing the injustices that the people face having to pay two power bills (electricity consumption and powerline rental).

Te Mangarautawhiri ā Pukehou Trust (TMaPT), members of Ngāti Hinemihi, has partnered with Ngā Wai à Te Tūi Māori and Indigenous Research Centre Unitec to develop this research project on behalf of their hapū. This research focuses on the aspirations of Ngāti Hinemihi whānau, and the social and health impacts of living with these high electricity payment demands. The aim of this research is to develop a framework of alternative and innovative energy that increases whānau technical capability to maintain their systems. 
As a recently inducted community researcher, it has been critical for me to grow my own local knowledge and networks whilst working with my own people. With that in mind, I have learnt the importance of mātauranga Māori systems. These are sustainable pathways that absolutely turn the dial on the degradation of Papatūānuku, safeguarding her for our mokopuna, as it will be those future generations that will continue to reshape, re-scope and re-energise the kaupapa of clean, renewable, sustainable energy systems that align to our tūpuna and our continued position of rangatiratanga of our own lands.

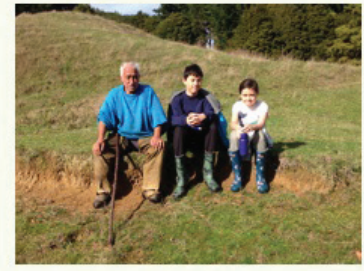

WHAKAPAKARI WHĀNAU Healthy Families

Sustainable Energy Options Empowering Whānau Restoring Power Sovereignty

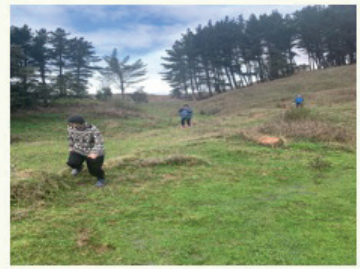

WHAI RAWA

\section{Economic Resourcing}

Natural and available resources

Business Opportunities Innovation

Partnerships both home and abroad

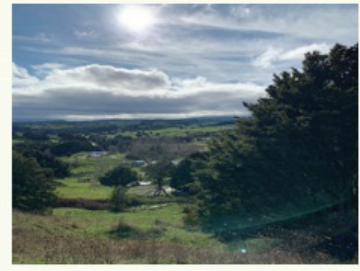

WHENUA MĀORI

Land Rich, Cash Poor? Switching the narrative Tino Rangatiratanga Mana Motuhake

Figure 2. Dad and his mokopuna, walking our whenua; papakāinga, June 2020.

Image: Collection of Hermione McCallum-Haire (nee Keepa), 2020.

\section{RESEARCH AIMS}

Our research aims have three overarching themes.

\section{Tuatahi:Whakapakari Whānau - Healthy Whānau:}

Exploring alternative sustainable energy options that can restore electricity back to whānau who have been financially forced to go without power for an extended period. This will give whānau the opportunity to have true 'power sovereignty', which is a critical component of positive whānau health and wellbeing outcomes in which whānau agency is increased.

\section{Tuarua:Whai Rawa - Economic Resourcing:}

The utilisation of whenua and kaitiakitanga for future commercial business innovation, and economic growth for the overall wellbeing of Te Mangarautawhiri a Pukehou Trust and Ngāti Hinemihi. Any future commercial opportunities will be underpinned by mātauranga Māori practices, thereby assuring sustainability. Preparing for an environment that will be economically, environmentally, socially, and culturally impacted by climate change is key to addressing this complex issue.

\section{Tuatoru:Whenua Māori:}

The development of alternative sustainable energy options would support the diverse types of whenua Māori, in the Ngāpuke region, allowing whānau to select the best technology for their land requirements. The ability to select a fit-for-purpose energy option could potentially encourage whānau to repatriate their whenua. 


\section{ELECTRICITY INDUSTRY REFORM ACT 1998:}

- THE ACT REQUIRED FULL OWNERSHIP SEPARATION OF DISTRIBUTION (LINES) BUSINESSES FROM SUPPLY (RETAIL AND GENERATION) BUSINESSES

- REASONING: TO ENCOURAGE COMPETITION IN GENERATION AND RETAILING TO PREVENT CROSS-SUBSIDISATION OF GENERATION AND RETAILING FROM LINES CUSTOMERS

- CROSS OWNERSHIP RESTRICTIONS WERE SUBSEQUENTLY RELAXED TWICE TO ALLOW LINES BUSINESSES TO OWN SOME GENERATION AND TO SELL THE OUTPUT FROM THOSE STATIONS

Figure 3. Compiled summary slide that was developed from the Electricity Industry Reform Act 1998 (No. 88). ${ }^{5}$

\section{THE PRICE OF POWER WOES INTHE TE ROHE PŌTAE AND TŪWHARETOA}

In the 1980s, the New Zealand Government commenced a review of the Crown's role in the electricity industry which triggered a series of reforms, policy changes, restructures, operational separation, bill amendments, various government boards, and so on. ${ }^{6}$ These eventuated in an Act that was to become the bane of every resident who lived in Te Rohe Pōtae (the King Country). In April 1998, the government announced a package of reforms for generation, distribution, and retail, including ownership separation of line and energy businesses.

The Electricity Industry Reform Act 1998 (the EIR Act) encouraged competition in the generation and retailing of electricity, the intent being to prevent cross-subsidisation of generation and retailing from lines customers. Cross ownership restrictions were subsequently relaxed twice to allow lines businesses to own some generation and to sell the output from those stations. Line ownership and management were not scrutinised in this modern-day gold rush when this state-owned enterprise, Transpower, was sliced up, and while the EIR Act was revoked by the Electricity Industry Act 20 I0,7 irreparable harm had already been done.

Fast-forward to 2007, the residents in Te Rohe Pōtae now receive two separate bills, one from their power provider (of which they have many choices). The other bill they receive is from The Lines Company, the network operator that owns and operates the very lines that deliver the power. The Lines Company (TLC) has its own formula that it uses to work out the rental of its lines to all its customers/consumers. The Lines Company looks at a consumer's 'top six' two-hour periods of use during the peak winter months from June to September. The formula is then used to work out a consumer's monthly charge, and that amount is then applied to the next 12 months of line rental. For some consumers, this is sometimes triple the bill from the actual electricity provider. This formula is quite complex and often presents random anomalies. In essence, the consumer will often end up paying more for the line rental than the actual power they consume. The complex 'load-based formula' was changed to a daily fixed charge as of April $2018,{ }^{8}$ but costs are still hefty in comparison to the rest of the country. Finally, if you disconnect from your power provider, TLC will still charge you that same monthly fee, because your whare (house) is physically connected to its network (TLC service cable to private premises). If you 'decommission' the line, a technician will come and retrieve the equipment, including the smart box that meters the power, and this is all free. However, if you wish to reconnect, there is a minimum reconnection fee of $\$ 300$ and a call-out fee for inspection of $\$ 100$ per hour, with other potential costs. The 'smart box' (owned by TLC) is the only metering box that is compatible with its service. 
The map below represents the reach of The Lines Company in Te Rohe Pōtae. It has a customer base of approximately 18,000, which includes my whānau and hapū.
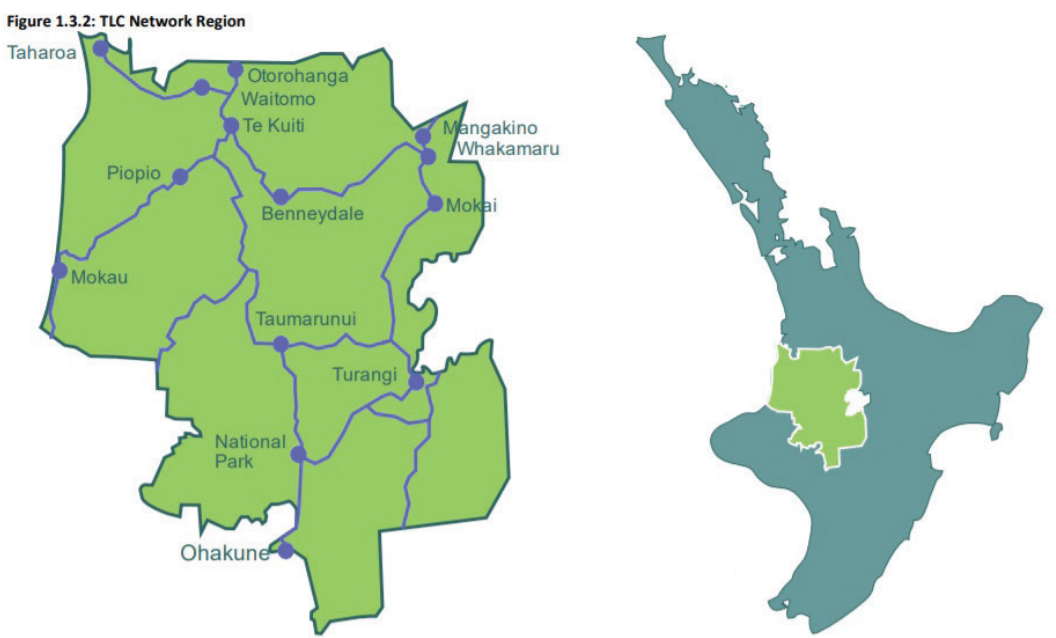

Figure 4. Map of The Lines Company's gamut. ${ }^{9}$

\section{WHAT'S THE WEATHER LIKE DOWN THERE?}

For many of our low-income whānau, kuia and kaumātua, high electricity costs have resulted in either going without, using a Lines Company timing system or resorting to unsafe practices of using candles, barbecues and gas heaters. Many just cannot afford to pay two power bills, so they are going without power all year round.

Our whānau are living in impoverished power environments, and the flow-on effects of expensive power pricing are having a detrimental impact on our tamariki, whānau māuiui, kuia and kaumātua.

This line graph highlights that the coldest nights can be as low as -5.0 degrees, while the hottest days can reach up to 33 degrees. Many local marae and kōhanga are impacted by power bill issues. Marae are the hub of whānau and hapū activities and, as we know, are busiest in winter months with tangihanga. Like other consumers, they too are affected by TLC's peak usage formula.

Regardless of whether you have the lights on or not, the fixed monthly line rental rate still applies. With no other options available to our people in and around Ngāti Hinemihi and Taumarunui, TLC is the reigning 'Power King of the King Country.'The story about the plight of the kuia and the financial stresses that she experienced is a typical example of the impact of the two bills that consumers in this area need to pay to have electricity here. 


\section{POWER POVERTY REALITY CHECK, A TRUE STORY}

A kuia in her mid-90s lives in a moderately insulated home and suffers from severe arthritis. Throughout the year, she requires a heat pump, an electric blanket, hot water, and occasional heater use. This easily leaves her with a monthly power bill of $\$ 300$ from her electricity provider. On top of that, she also must pay The Lines Company another $\$ 300$ per month.

With an annual income of $\$ 22,721.00$, her yearly power bill takes one third of that away. Our kuia also has to pay for specialist appointments, trips to Waikato Hospital, medication, living expenses, amongst other things. She is fortunate that her whānau take on this burden, when they themselves are struggling financially.

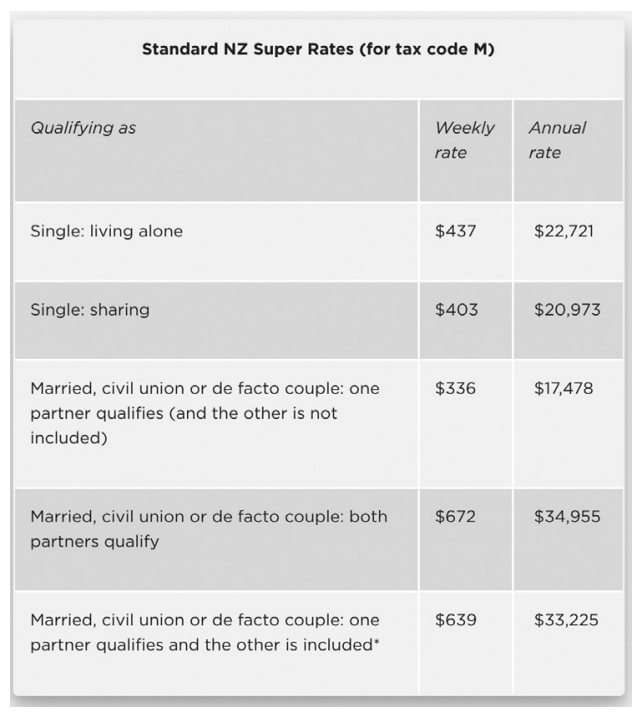

Figure 6. Current superannuation rates."

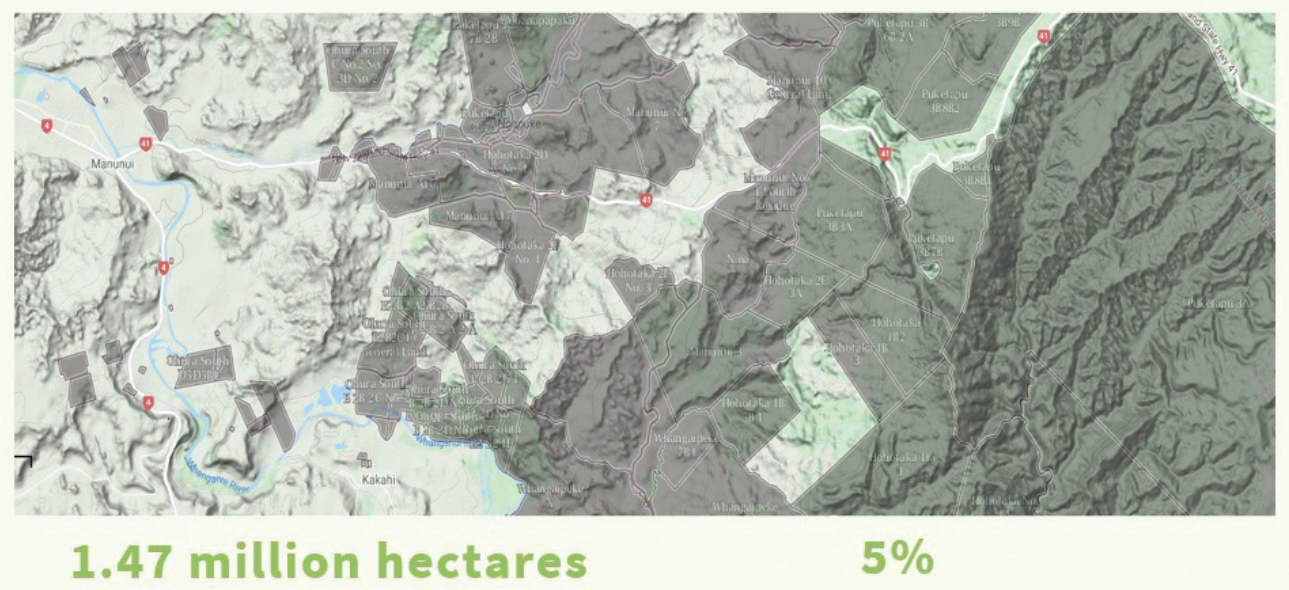

MĀORI FREEHOLD LAND

ALL LAND IN AOTEAROA

Figure 7. Māori freehold land. Source:Te Kooti Whenua Māori. ${ }^{12}$

\section{WHENUA MĀORI}

Currently there is approximately 1.47 million hectares of Māori land remaining in this country, ${ }^{13}$ about five per cent of all land in Aotearoa. The shaded areas on the map in Figure 7 provide a snapshot of whenua Māori that includes the Mangarautawhiri a Pukehou Trust's whenua, and various other land blocks that we hold shares in. This is land where Māori customary interests have been converted to freehold title by the Mãori Land Court or its predecessors by a freehold order. ${ }^{14}$ This land has therefore never been out of Māori ownership. 
If your whānau hold shares in Māori land blocks, you have no doubt heard at least once in your lifetime the phrase that we are "land rich but cash poor.'The Keepa whānau hold shares in various land blocks ranging from one 'owner' to several hundred. When I (Hermione McCallum-Haire) did a scan of my father's shares, it appeared that the larger the land block, or the closer it was to water, the greater the number of shareholders. Many of the other land blocks are non-arable, that is, there is a lack of sufficient fresh water, making the whenua unsuitable for cultivation or crop production. The Keepa papakāinga sits on a 9-hectare block that is 'owned' by dad, and according to the soil report from Landcare Research, the "potential of this land" is sub classed as '6e'; that is, the land is "suitable for grazing, production forestry, permanent carbon forests" with erosion susceptibility, deposition or the effects of past erosion damage limiting production. ${ }^{15}$ This quick environmental summary of our own whānau land would not be uncommon for many whānau living within the Ngāti Hinemihi region. Sun-exposed slopes, some situated in wind corridors, with a few that border rivers, lakes, and streams.

We do know that consolidation of Māori landshares is beneficial to all shareholders. Tuaropaki is an exceptional example where 297 landowners agreed to amalgamate their lands back in the 1950s and had their developmentscheme loan approved. With tenacity and self-determination, in 1994 the Tuaropaki Power Company Ltd was established and in 2000 became the 100 per cent owner of the 'Mokai I' 55 M. We now own and operate a geothermal power plant.16 Today the company's impressive portfolio has extended to food, nutraceuticals, communications, horticulture and, most recently, hydrogen energy. ${ }^{17}$ This extraordinary undertaking by our people is a reminder that, collectively, if we dream it, we can live it.

\section{Kauriki Marae}

Less than five minutes away from the Keepa whānau farm is Kauriki Marae, one of the three marae that are affiliated to Ngāti Hinemihi. It is in the Ngapuke Valley, which is hilly, in a wind corridor and has the Pungapunga River directly behind it. Most marae in Aotearoa will have a variety of natural resources within proximity and will have the ability to utilise these resources that all have the potential to generate energy.

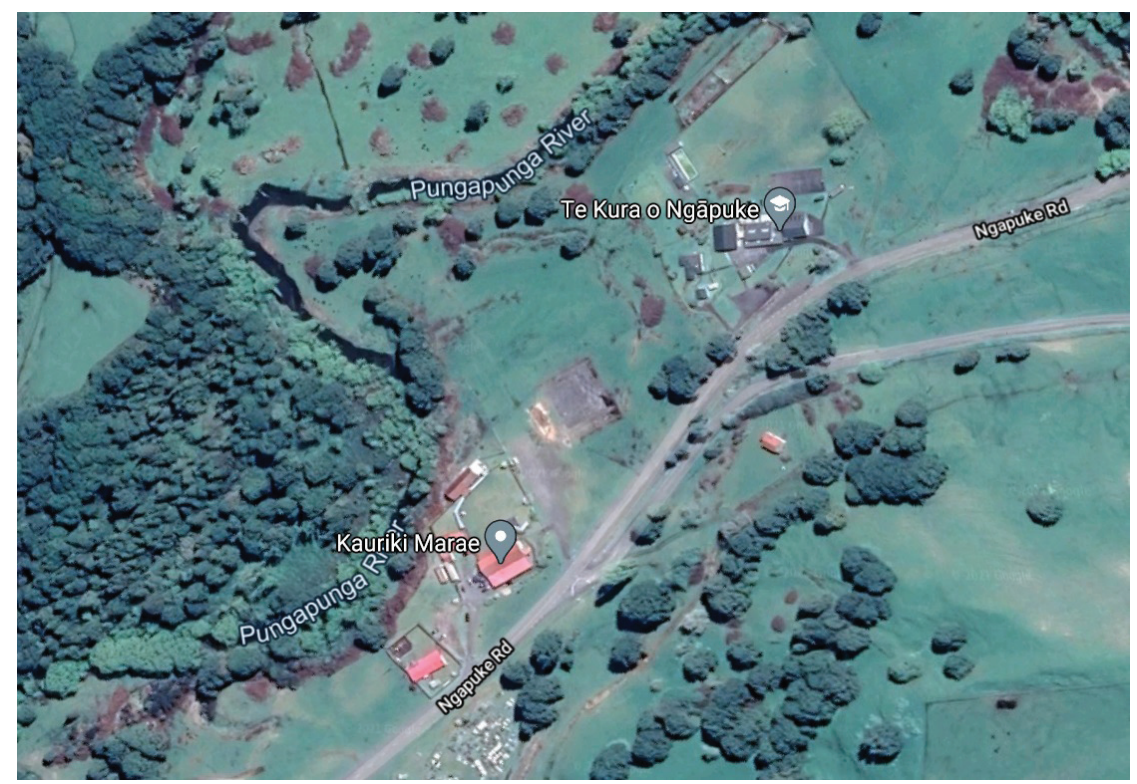

Figure 8. Kauriki Marae.

Source: Google Maps. https://www.google.co.nz/maps/place/Kauriki+Marae/@-38.88748I3, I75.4I2368I, 5 I 8m/data=!3m I! | e3!4m5!3m4! I s0×6d6b6d37809bd503:0xe7828356bf I 72eee!8m2!3d-38.88748 | 3!4d I 75.4| 4562 | 


\section{Innovation and Technology}

Over the past 30 years, the term 'sustainable technology' has become synonymous with renewable energies and sustainability. By looking to our natural world and pairing that with some of the most innovative technologies, we have a plethora of options that could enable and empower our whānau, iwi and hapū to operate completely offgrid.

Imagine a marae (and/or papakāinga) being completely powered by:

- Pūngao kōmaru (solar energy)

- Pūngao hau (wind energy)

- Hiko ā-awa (hydroelectricity)

With technology being developed and refined constantly, we have realistic and feasible opportunities to harness pūngao whakahou (renewable energy), to nourish and sustain our people for generations to come. Emerging disruptive technology can support our reclamation of our rangatiratanga and mana motuhake.

\section{“KO TŌKU PĀPĀ TËNEI, KO PATRICK TŌNA INGOA.”}

My dad climbed a ladder and physically cut the power lines that connected from the power pole on the road to our whare. He cut the lines in protest at the tyranny of The Lines Company and at yet another injustice that has been forced upon our people.

My dad has worked hard all his life, and he is now a retired master builder, although when something needs to be done, he is already getting the timber sorted. Like most of his generation, he can do many things. Dad can wire a television antenna from the top of a hill down to our whare, he can farm farm, break in a horse, make motorised go-kart vehicle hybrids, sort a home kill - his skill capacity is endless.

One of the aspects of this kaupapa will include technacy, so like Dad, we will look at the ingenuity, creativity, and engineering of the past, when our people could look after, install, fix and maintain their own technologies.

We know that when Ngai Māori are the designers, producers, and licensees of our own renewable energy products and services, we are our own dreams realised, the architects of our own futures. We could repurpose materials that are filling up the landfills and scrapyards, and formulate our own plastics and polymers made from only natural ingredients. Nau Mai Rā is New Zealand's first Māori retail power company that, according to cofounder Ezra Hira, is founded on a kaupapa of supporting vulnerable whānau Māori to access affordable electricity.

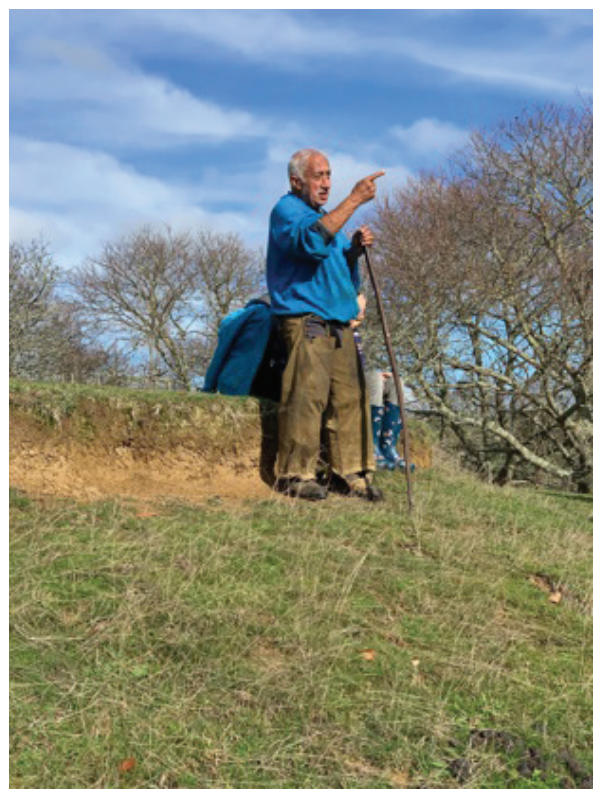

Figure 9. My dad is standing on the main ridge on our farm, retelling the whakapapa of the whenua, June 2020. As kaitiaki of our whenua, we all know that our levels of accountability must be enduring, the stories must be handed down from one generation to the next 'mō ake tonu.'

Photograph: Collection of Hermione McCallum-Haire (nee Keepa), 2021. In his words, "electricity is a right and not a luxury.",18 
Finally, this whakataukī reminds Hinemihi of the collective strength that is at the heart of positive whānau transformation toward a flourishing and prosperous future. A movement of whānau, of hapū, of Māori who are huddling together to produce our own answers, our own solutions, so that our mokopuna, the future kaitiaki of Aotearoa and all future descendants can thrive.

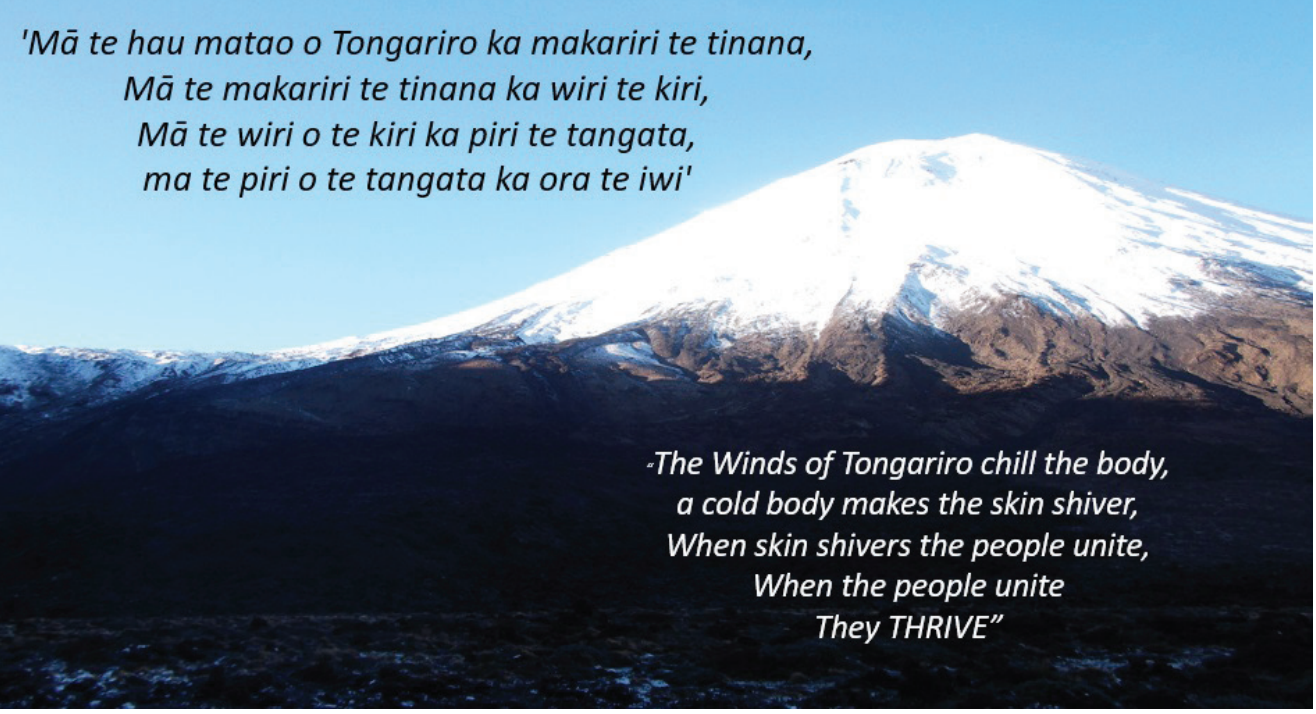

Ngā mihi nui kia koutou, tēnā koutou, tēnā koutou, tēnā koutou katoa.

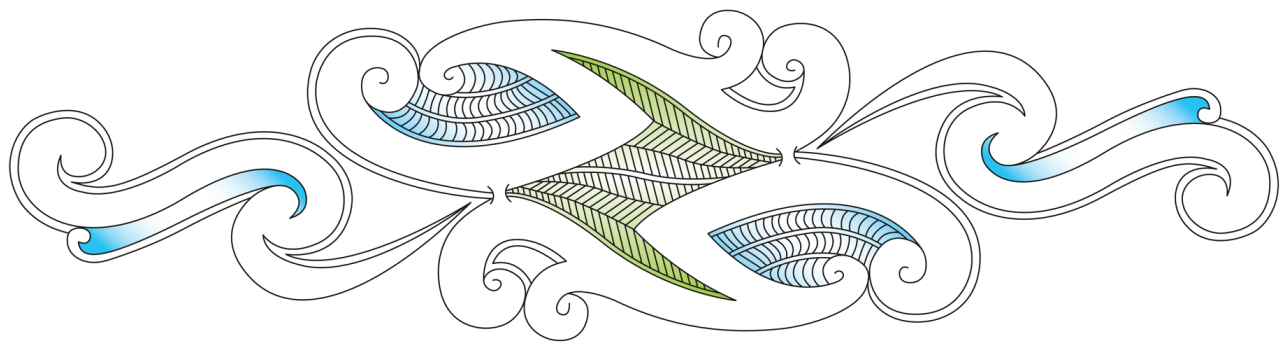


Hermione McCallum-Haire, Ngāti Tūwharetoa, Ngāti Maniapoto, Ngāti Raukawa ki te Tonga, Ngāti Haaua. Hermione McCallum-Haire (https://orcid.org/0000-0002-78II-8I5I) was born and raised in the small rural town of Taumarunui in the heart of the King Country. It is whakapapa which drives her to lead the charge for her whānau to address the issue of power inequity in her hāpori.Through her whānau trust and in partnership with Ngā Wai a Te Tūī, Māori and Indigenous Research Centre at the Unitec Institute of Technology, she is on the Pūnaha Hihiko:Vision Mātauranga MBIE funded placement scheme. Hermione is currently undertaking a Masters of Technological Futures with Tech Futures Lab and is continuing with this kaupapa to address power inequity in her rohe. She is looking forward to adapting emerging disruptive technologies to restore tino rangatiratanga through renewable clean energy innovations.

E. Rihi Te Nana, B. Ed, MA (Hons), Ngāti Haaua, Ngāpuhi,Tūwharetoa, Ngāti Maniapoto, Ngāti Raukawa. Rihi (https://orcid.org/0000-0003-0037-0936) has been working in the kaupapa Māori research space for over a decade committing her research ideas and knowledge to developing and empowering whānau and Māori communities to grow and maintain their agency by facilitating and building capability skills through kaupapa Māori research informed initiatives. As an experienced therapist, Rihi has worked alongside whānau groups to develop and strengthen whānau oranga and (health and well-being) tikanga practices. Historically, Rihi has had many years within the social services sector supporting Māori strategic development that has linked Iwi Hauora and Whānau Ora plans to government funding and resourcing.

Joanne Gallagher, Te Aupōuri, Ngāti Whātua. Jo is a Research Administrator for Ngā Wai a Te Tūi, UNITEC's Māori and Indigenous research centre. In this role, she provides support for the researchers across various projects. Jo is an avid learner and teacher of Te Reo Māori as she continues to pursue study in this area. Jo is passionate about her people, her whānau, iwi and hapū, which guide her as she navigates her mahi. 
I John Te Herekiekie Grace, Tuwharetoa:The History of the Māori People of the Taupo District (Wellington: Reed, 1959 ), I03.

2 Ibid.

3 Ibid.

4 lulia Leilua, "Native Affairs - Power Play - Part I," Native Affairs, July 13, 20 I5, https://www.teaomaori.news/native-affairspower-play-part- I; lulia Leilua, "Native Affairs - Power Play - Part 2," Native Affairs, July I3, 20 I 5, https://www.teaomaori.news/ native-affairs-power-play-part-2.

5 Electricity Industry Reform Act 1998 (No 88), http://www.nzlii.org/nz/legis/hist_act/eiral 9981998n88357/.

6 Energy markets Policy Energy \& Resources Branch 2015 Chronology of New Zealand electricity reform https://www.mbie.govt. nz/assets/2ba6419674/chronology-of-nz-electricity-reform.pdf

7 Electricity Industry Act 2010 (No. I | 6), https://legislation.govt.nz/act/public/20 I 0/0 I I 6/latest/whole.htm|\#DLM2634233.

8 The Lines Company, 2018 Pricing Policy (Te Kuiti:The Lines Company), I I, https://www.thelinescompany.co.nz/site/uploads/ Policies/2018-Pricing-Policy.pdf

9 The Lines Company, 2018 Asset Management Plan (Te Kuiti:The Lines Company), I I, https://www.thelinescompany.co.nz/site/ uploads/Disclosures/AssetManagementPlans/20 I8-Asset-Management-Plan.pdf.

10 Metservice, "Past Weather for Taumarunui," accessed April 16, 2021, https://www.metservice.com/towns-cities/locations/ taumarunui/past-weather.

II Sorted, "NZ Super Rates - How Much is New Zealand Superannuation?" accessed April 16, 2021, https://sorted.org.nz/ guides/retirement/this-years-nz-super-rates/.

12 Māori Land Online, "Te Kooti Whenua Māori," accessed April 16, 2021, https://www.maorilandonline.govt.nz/gis/home. htm?moj_URL=https\%3A\%2F\%2Fwww.justice.govt.nz\&nzGovt_URL=http\%3A\%2F\%2Fnewzealand.govt.nz\&contactUs_ URL=http\%3A\%2F\%2Fwww.maorilandcourt.govt.nz\%2Fcontact-us\&feedback_URL=https\%3A\%2F\%2Fconsultations.justice. govt.nz\%2Foperations-service-delivery\%2Fmlc-customer-survey\&helpDoc_URL=https\%3A\%2F\%2Fmaorilandcourt.govt. nz\%2Fabout-mlc\%2Fpublications\%2F\%23other-guides\&mlc_URL=https\%3A\%2F\%2Fwww.maorilandcourt.govt.nz

13 Community Law, "Status Māori Land:Types of Māori Land," accessed April I6, 2021, https://communitylaw.org.nz/communitylaw-manual/chapter-2-maori-land/status-of-maori-land/\#: :text=Whenua\%20M\%C4\%8 I ori\%20Act.-,M\%C4\%8 I ori\%20 freehold\%20land,been\%20out\%20 f\%20M\%C4\%8 I ori\%20ownership.\&text=M\%C4\%8 I ori\%20freehold\%20land\%20 continues\%20to,Land\%20Court\%20changes\%20its\%20status; Te Ture Whenua Māori Act 1993, s 4 (definition of "Māori land"), s 129.

14 Ibid.

I5 Manaaki Whenua / Landcare Research, "New Zealand Land Resource Inventory (NZLRI)," accessed April 20, 202I, https:// whenuaviz.landcareresearch.co.nz/Explanation\#luc.

16 Tuaropaki Trust, "Our History," accessed April 20, 2021, http://www.tuaropaki.com/our-story/our-history/.

17 Tuaropaki Trust, "Our Business," accessed April 20, 2021, http://www.tuaropaki.com/our-story/our-business/.

18 Jehan Casinader, '“'Many of our energy assets are built on Māori land is why do Māori endure power poverty?" Stuff, May 29, 202I, https://www.stuff.co.nz/business/I 25262459/many-of-our-energy-assets-are-built-on-mori-land-so-why-do-moridisproportionately-endure-power-poverty. 